\title{
Influence of Drip Fertigation Levels on Physiological Parameters of Aerobic Rice in Western Zone of Tamil Nadu, India
}

\author{
S. Ramadass* and S.P. Ramanathan \\ ${ }^{1}$ Department of Agronomy, TNAU, Coimbatore-03, India \\ ${ }^{2}$ Department of Agronomy, WTC, TNAU, Coimbatore-03, India \\ *Corresponding author
}

\begin{tabular}{|c|c|}
\hline & A B S T R A C T \\
\hline Keywords & \multirow{5}{*}{ 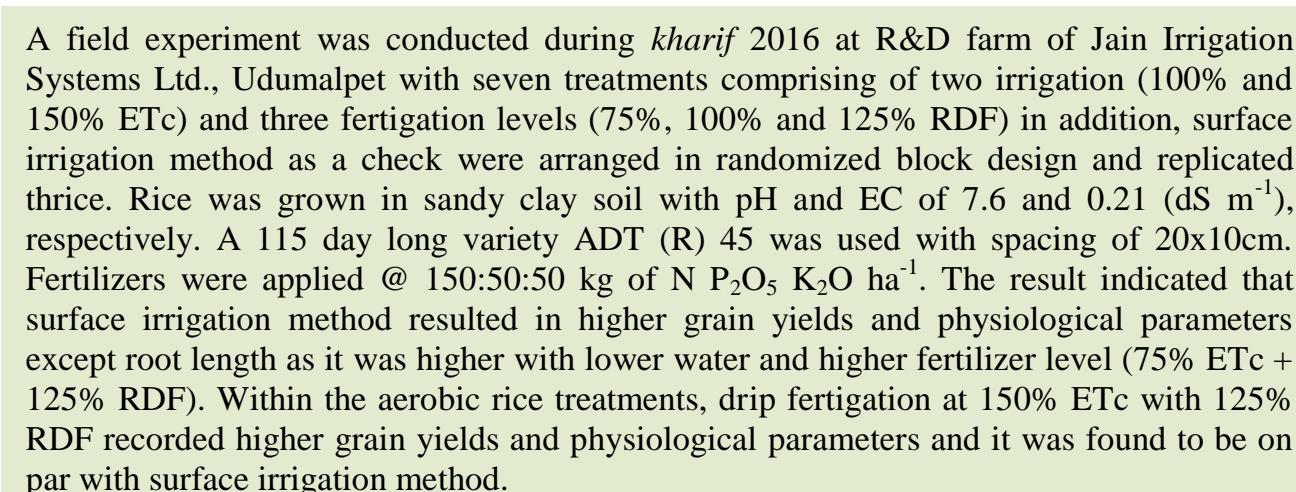 } \\
\hline $\begin{array}{l}\text { Aerobic rice, } \\
\text { Drip fertigation, } \\
\text { Physiological } \\
\text { parameters, } \\
\text { Grain yield }\end{array}$ & \\
\hline Article Info & \\
\hline $\begin{array}{l}\text { Accepted: } \\
20 \text { March } 2017\end{array}$ & \\
\hline $\begin{array}{l}\text { Available Online: } \\
10 \text { April } 2017\end{array}$ & \\
\hline
\end{tabular}

\section{Introduction}

Rice (Oryza sativa L.) is one of the most important staple food crops of the world. More than two billion people in Asia are getting 60 to 70 per cent of their energy requirement from rice and its derived products. Worldwide, rice is being cultivated in an approximate area of 147 million hectares with a total production of 525 million tonnes and average productivity of $3571 \mathrm{~kg}$ $\mathrm{ha}^{-1}$. Asia contributes 59 per cent of world population and accounts for 92 per cent of global rice production. Among many food grains cultivated in India, rice has the pride of being cultivated over an area of 43.97 million hectares with a production of 104.32 million tonnes which contributes to 41.5 per cent of total food grain production of our Country (Anonymous, 2014). Over the past decade, we have witnessed a growing scarcity and competition for water around the world. As the water demand for domestic, municipal, industrial and environmental purposes rises in the near future, the water availability for agriculture sector gets affected. The estimated water availability for agriculture which is 83.3 per cent of total water used today will shrink to 71.6 per cent in 2025 and to 64.6 per cent in 2050 (Yadav, 2002). The future of rice production which consumes a lion's share of water $(85 \%)$ used in irrigated agriculture (Barker et al., 1999) will therefore depend heavily on developing and adopting 
technologies and practices which will use less water with highest use efficiency. Aerobic rice is a production system in which specially developed "aerobic rice" varieties are grown in well-drained, non- puddled and non saturated soils. With appropriate management, the system aims for yields of at least 4-6 tons per hectare. Yields were on par with irrigated puddle rice with an average of 5.5 to $6 \mathrm{t} \mathrm{ha}^{-1}$ with 60 per cent less water. Keeping the above facts in mind, the present study was conducted with following objectives; to assess the effect of different irrigation and Fertigation levels on physiological parameters and yield of direct seeded drip irrigated aerobic rice.

\section{Materials and Methods}

A field experiment was conducted in the Research and Development Farm of Jain Irrigation Systems Ltd., located in the Udumalpet Taluk of Tirupur District (TN). The farm is situated in the Western Agro climatic zone of Tamil Nadu at $10^{\circ} 34^{\prime} 48^{\prime}$ ' $\mathrm{N}$ latitude and $77^{\circ} 14^{\prime} 24^{\prime}$ ' E longitude and at an altitude of $340.46 \mathrm{~m}$ above MSL. The soil of the experimental field is sandy clay with good drainage. The available soil nitrogen, phosphorous and potassium were 196, 6.5 and $350 \mathrm{~kg} \mathrm{ha}^{-1}$, respectively with soil $\mathrm{pH}$ and EC of 7.66 and $0.21 \mathrm{dS} \mathrm{m}^{-1}$. The experiment was conducted during kharif 2016 with seven treatments comprising of two irrigation $(75 \%$ and $100 \%$ ETc) and three fertigation levels (75\%, $100 \%$ and $125 \%$ RDF) in addition, surface irrigation method were arranged in randomized block design and replicated thrice. Surface irrigation was given one day after disappearance of ponded water to depth of $2.5 \mathrm{~cm}$ with manual application of fertilizers. Proper weed management and plant protection measures were carried out at the appropriate time as per the recommendation. Raised beds were formed with a top bed width of $100 \mathrm{~cm}$ and furrows with width of $30 \mathrm{~cm}$ and the crop spacing adopted is $20 \mathrm{~cm} \times 10 \mathrm{~cm}$.

Five plant samples in each replication were drawn at active tillering (AT) and panicle initiation (PI) for recording various physiological characters. To overcome border effect observations were made on middle plants in the row. The data obtained were subjected to statistical analysis and were tested at five per cent level of significance to interpret the treatment differences as suggested by Gomez and Gomez (1984).

\section{Results and Discussion}

\section{Effect of drip fertigation on rice root characters}

The root characters recorded at active tillering and panicle initiation stage differed due to different levels of irrigation and fertigation.

\section{Root length}

Among the treatments lower irrigation level with high fertilizer level recorded increased root length (Table 1). Drip Fertigation at $100 \% \mathrm{ETc}+125 \% \mathrm{RDF}\left(\mathrm{T}_{3}\right)$ recorded higher root length at both the stages as compared to all other treatments and it was followed by $100 \%$ ETc $+100 \%$ RDF $\left(\mathrm{T}_{2}\right)$. Vijayakumar (2009) stated that under water deficit situation, even the susceptible varieties produced slender and long roots to absorb moisture from lower layers. In the present study lower irrigation level might have put forth deeper and lengthier roots. Change in variation in moisture content in the root zone might have caused the plant root to spend more energy to extract the water and nutrients from the deeper layer and ultimately resulted in higher root length and dry weight (Narendra Pandey et al., 2010). 


\section{Root volume}

Root volume (Table 1) was greatly influenced by various irrigation and fertilizer amounts. Surface irrigation treatment resulted in higher root volume of 16.3 and $22.8 \mathrm{cc} \mathrm{hill}^{-1}$ at AT and PI stage respectively. Among the drip irrigation treatments $150 \%$ ETc with $125 \%$ $\mathrm{RDF}\left(\mathrm{T}_{6}\right)$ registered higher root volume with the values of 15.9 and $22.3 \mathrm{cc} \mathrm{hill}^{-1}$.

However $T_{6}$ showed on par value with surface irrigation method. This was mainly because of application of water and nutrients directly to the root zone make them easily available and also maintaining moist condition around root zone which creates favourable environment for roots to grow and absorb water and nutrients more effectively. This finding is in agreement with the findings of Govindan and Grace (2012).

\section{Root dry weight}

Various irrigation and fertigation levels on root dry weight (Table 1) of rice were significantly influenced.

Data on root volume revealed that the surface irrigation $\left(\mathrm{T}_{7}\right)$ observed higher values of 3.79 and $6.41 \mathrm{~g} \mathrm{hill}^{-1}$ followed by irrigation at 100 $\%$ ETc with $125 \% \operatorname{RDF}\left(\mathrm{T}_{6}\right)$ at both the stages. This might be due to the optimum moisture, nutrient and better aeration under drip irrigation which in turn have increased the root dry weight (Vijaykumar, 2009). Similarly, this result is in accordance with the findings of Govindan and Grace (2012).

\section{Effect of drip fertigation on leaf area index, chlorophyll value and crop growth rate}

Irrespective of growth stages the physiological parameters like leaf area index, chlorophyll index and crop growth rate was greatly influenced by different irrigation regimes and fertigation levels.

\section{Leaf Area Index (LAI)}

At both the stages of crop growth, higher the LAI was observed with surface irrigation method (Table 1). Within the drip irrigation treatments DF at $150 \%$ ETc with $125 \%$ RDF recorded higher LAI. This was on par with $150 \%$ ETc with $100 \%$ RDF.

The reduction in LAI with lower irrigation and fetigation levels (100\% ETc with $75 \%$ $\mathrm{RDF}$ ) might be due to reduced turgor pressure under moisture stress conditions which affected the leaf cell expansion. Similar observations were also made by Nguyen et al., (2009) and Bouman et al., (2005). The Increased leaf area index could be attributed to the increased functional leaf area and delayed leaf senescence by production of phytohormones that enhanced cell division and elongation (Elankavi et al., 2009).

\section{Chlorophyll index}

In general leaf chlorophyll value was progressively increased from active tillering to panicle initiation (Table 2). The leaf chlorophyll index was found to be significantly higher with surface irrigation treatment at both the stages with values of 32.91 and 36.33 and it was at par with DF at $150 \%$ ETc with $125 \%$ RDF $\left(\mathrm{T}_{6}\right)$.

Stress fewer conditions prevailed during the growth period of rice must have increased the chlorophyll content there by increased greenness owing higher chlorophyll content. Increased leaf chlorophyll content led to increased photosynthetic rate and more dry matter production (Mohan et al., 2000). These findings were also in conformity with the findings of Vanitha (2008). 
Table.1 Root characters and LAI of aerobic rice as influenced by drip irrigation and fertigation levels

\begin{tabular}{|c|c|c|c|c|c|c|c|c|}
\hline \multirow[t]{2}{*}{ Treatments } & \multicolumn{2}{|c|}{$\begin{array}{c}\text { Root } \\
\text { Length } \\
(\mathbf{c m}) \\
\end{array}$} & \multicolumn{2}{|c|}{$\begin{array}{l}\text { Root volume } \\
\quad\left(\text { cc hill }{ }^{-1}\right)\end{array}$} & \multicolumn{2}{|c|}{$\begin{array}{c}\text { Root dry } \\
\text { weight } \\
\left(\text { g hill }^{-1}\right) \\
\end{array}$} & \multicolumn{2}{|c|}{ LAI } \\
\hline & $\mathbf{A T}$ & PI & AT & PI & $\mathbf{A T}$ & PI & AT & PI \\
\hline $\mathrm{T}_{1}-\mathrm{DF}$ at $100 \%$ ETc with $75 \% \mathrm{RDF}$ & 17.1 & 23.6 & 12.8 & 18.0 & 2.98 & 5.05 & 2.98 & 3.95 \\
\hline $\mathrm{T}_{2^{-}} \mathrm{DF}$ at $100 \%$ ETc with $100 \% \mathrm{RDF}$ & 18.3 & 25.3 & 13.7 & 19.2 & 3.18 & 5.38 & 3.13 & 4.15 \\
\hline $\mathrm{T}_{3}-\mathrm{DF}$ at $100 \%$ ETc with $125 \% \mathrm{RDF}$ & 19.1 & 26.4 & 14.3 & 20.1 & 3.33 & 5.64 & 3.25 & 4.30 \\
\hline $\mathrm{T}_{4}-\mathrm{DF}$ at $150 \%$ ETc with $75 \% \mathrm{RDF}$ & 15.7 & 21.7 & 14.2 & 19.9 & 3.30 & 5.59 & 3.24 & 4.29 \\
\hline $\mathrm{T}_{5}-\mathrm{DF}$ at $150 \%$ ETc with $100 \% \mathrm{RDF}$ & 17.0 & 23.5 & 15.1 & 21.3 & 3.52 & 5.96 & 3.42 & 4.53 \\
\hline $\mathrm{T}_{6-}$ DF at $150 \%$ ETc with $125 \%$ RDF & 17.2 & 23.8 & 15.9 & 22.3 & 3.70 & 6.26 & 3.55 & 4.70 \\
\hline $\mathrm{T}_{7-}$ SI with soil application of $100 \% \mathrm{RDF}$ & 16.5 & 22.8 & 16.3 & 22.8 & 3.79 & 6.41 & 3.64 & 4.81 \\
\hline S Ed & 0.4 & 0.6 & 0.3 & 0.4 & 0.06 & 0.10 & 0.09 & 0.12 \\
\hline $\mathrm{CD}(\mathrm{P}=\mathbf{0 . 0 5})$ & 1.0 & 1.3 & 0.6 & 0.8 & 0.14 & 0.23 & 0.20 & 0.25 \\
\hline $\begin{array}{c}\text { Note: DF- Drip Fertigation } \\
\text { SI - Surface Irrigation }\end{array}$ & $\begin{array}{l}\text { Evapo } \\
\text { ommen }\end{array}$ & $\begin{array}{l}\text { nspirat } \\
\text { d Dose }\end{array}$ & f Fertili & & Pani & itiati & & \\
\hline
\end{tabular}

Table.2 Chlorophyll index, crop growth rate (CGR) and grain yield of aerobic rice as influenced by drip irrigation and fertigation levels

\begin{tabular}{|c|c|c|c|c|c|}
\hline \multirow[t]{2}{*}{ Treatments } & \multicolumn{2}{|c|}{$\begin{array}{c}\text { Chlorophyll } \\
\text { index }\end{array}$} & \multicolumn{2}{|c|}{$\begin{array}{c}\text { CGR } \\
\left(\mathrm{g} \mathrm{m}^{-2} \text { day }^{-1}\right)\end{array}$} & \multirow{2}{*}{$\begin{array}{l}\text { Grain } \\
\text { yield }\end{array}$} \\
\hline & AT & PI & AT-PI & PI-F & \\
\hline $\mathrm{T}_{1}-\mathrm{DF}$ at $100 \%$ ETc with $75 \% \mathrm{RDF}$ & 27.13 & 29.95 & 27.13 & 29.95 & 3741 \\
\hline $\mathrm{T}_{2}-\mathrm{DF}$ at $100 \%$ ETc with $100 \% \mathrm{RDF}$ & 28.48 & 31.45 & 28.48 & 31.45 & 4152 \\
\hline $\mathrm{T}_{3}-\mathrm{DF}$ at $100 \%$ ETc with $125 \% \mathrm{RDF}$ & 29.57 & 32.65 & 29.57 & 32.65 & 4448 \\
\hline $\mathrm{T}_{4}-\mathrm{DF}$ at $150 \%$ ETc with $75 \% \mathrm{RDF}$ & 29.45 & 32.52 & 29.45 & 32.52 & 4343 \\
\hline $\mathrm{T}_{5}-\mathrm{DF}$ at $150 \%$ ETc with $100 \% \mathrm{RDF}$ & 30.98 & 34.21 & 30.98 & 34.21 & 4821 \\
\hline $\mathrm{T}_{6^{-}}$DF at $150 \%$ ETc with $125 \%$ RDF & 32.16 & 35.51 & 32.16 & 35.51 & 5110 \\
\hline $\mathrm{T}_{7}-$ SI with soil application of $100 \% \mathrm{RDF}$ & 32.91 & 36.33 & 32.91 & 36.33 & 5304 \\
\hline S Ed & 0.08 & 0.88 & 0.53 & 0.58 & 176 \\
\hline $\mathrm{CD}(\mathrm{P}=\mathbf{0 . 0 5})$ & 1.80 & 2.03 & 1.20 & 1.33 & 420 \\
\hline
\end{tabular}

Note: DF- Drip Fertigation $\quad$ ETc - Crop Evapotranspiration

SI - Surface Irrigation

RDF - Recommended Dose of Fertilizer

AT-Active tillering

PI- Panicle Initiation

\section{Crop growth rate (CGR)}

Different drip fertigation levels significantly influenced the rate of rice crop growth at different stages (Table 2). The higher CGR was observed with surface irrigation $\left(T_{7}\right)$. Among the drip irrigation treatment higher dip fertigation level (150\% ETc with $125 \%$ RDF $\left(\mathrm{T}_{6}\right)$ ) recorded the higher CGR. The higher crop growth rate at higher nutrient and water levels might have resulted in the accumulation of relatively more dry matter through increased photosynthetic efficiency due to optimum leaf area (Ombir Singh et al., 2007).

Effect of drip fertigation on grain yield of aerobic rice

Irrigation and fertigation schedules significantly influenced the grain yield of rice 
(Table 2). Surface irrigation method registered higher grain yield (5304 $\mathrm{kg} \mathrm{ha}^{-1}$ ) and it was on par with $150 \%$ ETc with $125 \%$ $\operatorname{RDF}\left(T_{6}\right)$ with yield of $5110 \mathrm{~kg} \mathrm{ha}^{-1}$. The higher grain yield of aerobic rice might be associated with increase in growth and physiological characters were observed under higher moisture regime. These findings were in agreement with results of Gupta et al., (2003). And also, the higher grain yield was might be due to increase in yield attributing characters under high soil moisture regime as a result of frequent irrigation (Shekara et al., 2010).

It can be concluded that in water stressed areas drip irrigation at $150 \%$ ETc with $125 \%$ RDF fertigation may be adopted. The surface irrigation can be totally replaced by this treatment for sustained rice productivity.

\section{References}

Anonymous, 2014. Agricultural statistics at a glance. Directorate of Economics and Statistics, New Delhi.

Barker, R., D. Dawe, T. P. Tuong, S. I. Bhuiyan and Guerra, L. C., 1999, The outlook for water resources in the year 2020: Challenges for research on water management in rice production. In: Assessment and orientation towards the 21st Centuary. Procedings of 19th session of the International Rice Commission. Cairo. Egypt. 7-9. September, 1998. Rome: FAO pp. 96-109.

Bouman, B.A.M., Peng, S., Castaneda, A.R and Visperas, R M. 2005. Yield and water use of irrigated tropical aerobic rice systems. Agric. Water Manage. 74: 87-105.

Elankavi S., G. Kuppuswamy, V. Vaiyapuri and R. Raman. 2009. Effect of phytohormones on growth and yield of rice. Oryza, 46(4): 310-313.

Gomez, K.A. and A.A. Gomez. 1984. Statistical Procedures for Agricultural research. (Eds.).
John Wiley and Sons., New York, p. 680.

Govindan, R and T. Myrtle Grace. 2012. Influence of Drip Fertigation on growth and yield of rice varieties (Oryza sativa L.). Madras Agric. J., 99(4-6): 244-247.

Gupta, R.K., Naresh, R.K., Hobbs, P,R,, Zheng Jiaguo and Ladha, J.K. 2003. Sustainability of postgreen revolution agriculture: the rice-wheat cropping systems of the Indo-Gangetic Plains and China. (In) 'Improving the Productivity and sustainability of Rice- Wheat systems: Issues and Impacts, 1-25.

Mohan, M.M., N.S. Luxmi and S.N. Ibrahim. 2000. Chlorophyll stability index (CSI): its impact on salt tolerance in rice. International Rice Res. Notes, 25:38-39.

Narendra Pandey, A.K. Verma and R.S. Tripathi. 2010. Response of hybrid rice to scheduling of Nitrogen and irrigation during dry season. Oryza, 47(1): 34-37.

Nguyen, H.T., Fischer, K.S and Fukai, S. 2009. Physiological responses to variouswater saving systems in rice. Field Crops Res. 112: 189-198.

Ombir Singh, Prempal Singh and Sandeep Kumar. 2007. Maximization of rice (Oryza sativaL.) yield through heavy fertilization and its residual effect on wheat (Triticum aestivum) under ricewheat cropping system. Ann. Agric. Res. New Series, 28(2): 137-140.

Shekara, B.G and Sharanappa, K.N. 2010. Effect of irrigation schedules on growth and yield of aerobic rice (Oryza sativa L.) under varied levels of farmyard manure in Cauvery command area. Indian J. of Agron. 55 (1): 35-39.

Vanitha, K. 2008. Drip fertigation and its physiological impact in aerobic rice (Oryza sativa L.) M.Sc.,Thesis submitted to Tamil Nadu Agricultural University, Coimbatore, India.

Vijayakumar, P. 2009. Optimization of water and nutrient requirement for yield maximization in hybrid rice under drip fertigation system rice (Oryza sativa L.). M.Sc., Thesis submitted to Agricultural College and Research Institute, Tamil Nadu Agricultural University, Madurai.

Yadav, J. S. P. 2002, Conservation and managing water resource for sustainable agriculture. J. Water Manage., 10(1-2): 1-10.

\section{How to cite this article:}

Ramadass, S. and Ramanathan, S.P. 2017. Influence of Drip Fertigation Levels on Physiological Parameters of Aerobic Rice in Western Zone of Tamil Nadu, India. Int.J.Curr.Microbiol.App.Sci. 6(4): 2609-2613.Doi : https://doi.org/10.20546/ijcmas.2017.604.303 